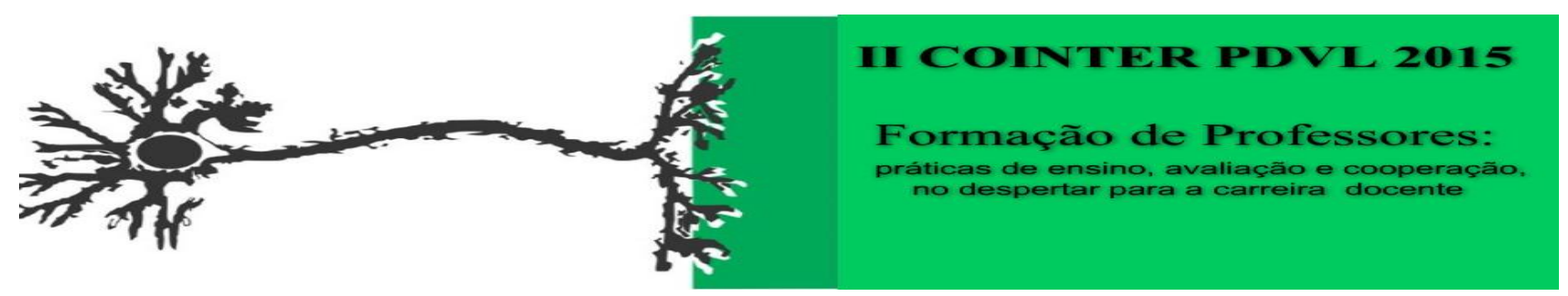

\title{
APRENDIZAGEM DO CONCEITO DE SUSTENTABILIDADE ATRAVÉS DA EDUCAÇÃO AMBIENTAL DOS TRABALHADORES DO CAMPO DE UMA INDÚSTRIA SUCROALCOOLEIRA: UM RELATO DE EXPERIÊNCIA
}

\author{
Apresentação: Relato de Experiência \\ Valquíria do Nascimento Tavares ${ }^{1}$; Inaldo Jerfson Sobreira da Silva ${ }^{2}$
}

\section{Introdução}

Esse relato foi elaborado durante a realização de um estágio supervisionado na área de Química, com a parceria entre UFRPE - Universidade Federal Rural de Pernambuco e uma usina sucroalcooleira da Zona da Mata de Pernambuco onde foram realizados estudos acerca das formas de descartes dos subprodutos através da educação ambiental dos trabalhadores do campo a fim de gerenciar o uso dos resíduos químicos formados pela fabricação do açúcar e álcool.

Durante as atividades foram apresentadas situações problematizadoras onde foram geradas discussões a respeito da importância do trabalhador do campo ser contribuinte na promoção da sustentabilidade socioambiental, através das formas de reduzir o impacto ambiental, da aplicação correta e consciente dos resíduos oriundos da produção do açúcar e álcool e alternativas eficientes que possam proporcionar uma produção mais limpa no âmbito da educação ambiental.

Diante dessa situação o objetivo desse artigo é abordar as questões ambientais inerentes ao setor sucroalcooleiro, seus impactos e também as alternativas de eficiência proporcionada pela Produção Mais Limpa através da educação ambiental dos trabalhadores do campo.

\section{Relato de Experiência}

A pesquisa foi aplicada no campo onde fica a plantação de cana-de-açúcar da empresa. Os trabalhadores do campo eram reunidos em grupos, ao ar livre e a metodologia aplicada foi a da pesquisa qualitativa. Estudos qualitativos têm sido indicados para verificar de que maneira pessoas avaliam uma experiência, uma ideia; como elas definem um problema, suas opiniões e sentimentos envolvidos nesse processo (IERVOLINO e PELICIONI, 2001), o que representa, em outras palavras, analisar e interpretar aspectos mais profundos (MARCONI e LAKATOS, 2004).

\footnotetext{
${ }^{1}$ Mestranda do Programa de Pós Graduação em Engenharia Ambiental - PPEAMB da Universidade Federal Rural de Pernambuco - UFRPE. E-mail: valquiria_quimica@hotmail.com.

${ }^{2}$ Mestrando do Programa de Pós Graduação em Ensino das Ciências da Universidade Federal Rural de Pernambuco UFRPE. E-mail:inaldojerfson@hotmail.com.
} 
A análise das entrevistas realizadas baseou-se na metodologia do discurso do sujeito coletivo (DSC), conforme Lefèvre, Lefèvre e Teixeira (2000). O quantitativo desses trabalhadores foi determinado de acordo com a necessidade de cada área; para esse trabalho observou-se áreas com médias de grupos entre 5 a 8 trabalhadores por área, os quais eram subdivididos em grupos focais dependendo da localidade, dificuldade de acesso.

Inicialmente foram verificadas as percepções dos trabalhadores a respeito de meio ambiente, educação ambiental e seus interesses por temas dessa área. Posteriormente foram indagados sobre suas responsabilidades na conservação do meio ambiente e suas ações. E finalmente foram questionados sobre as formas de impactos ambientais gerados pela indústria, as relações desse impacto com a sua saúde e de sua família, os contaminantes e tratamentos químicos presente no seu ramo de trabalho e como fazer para minimizar as agressões causadas por esses poluentes.

\section{Considerações}

Pode-se observar que, em geral, a noção de conservação do meio ambiente por parte dos trabalhadores do campo eram voltadas para ações do cotidiano como coleta seletiva, não jogar lixo na rua e em rios, economizar água; porém em nenhum momento foram relatadas suas responsabilidades no âmbito profissional.

Após os trabalhadores entenderem como seu trabalho era importante para a sustentabilidade ambiental, os resultados positivos foram notórios quanto à contribuição para o desempenho responsável dos trabalhadores.

Quanto à empresa, fica a responsabilidade de promover ações de continuidade através de processos de Educação Ambiental que visam à construção de valores sociais, habilidades, atitudes, conhecimento e competências, voltadas para a conservação do meio ambiente.

\section{Referências}

IERVOLINO, S.A.; PELICIONI, M.C.F. A utilização do grupo focal como metodologia qualitativa na promoção da saúde. Rev Esc Enf USP, v. 35, n.2, p.115-21, jun, 2001.

LEFÈVRE, F; LEFÈVRE A. M. C; TEIXEIRA J.J.V. O Discurso do sujeito coletivo: uma nova abordagem metodológica em pesquisa qualitativa. Caxias do Sul: EDUCS, 2000.

MARCONI, M. A.; LAKATOS, E. M. Metodologia Científica. 4 ed. São Paulo: Atlas, 2004. 